\title{
Ser Mãe de Criança com Microcefalia: Do Ideal ao Real na Síndrome Congênita do Zika Vírus (SCZV)
}

\author{
Jany Helem de Almeida Santos ${ }^{1}$ \\ ${ }^{1}$ Centro Universitário Maurício de Nassau, PB, Brasil.
}

\author{
Aponira Maria de Farias ${ }^{2}$ \\ ${ }^{2}$ FioCruz Minas - Instituto René Rachou, PB, Brasil.
}

\begin{abstract}
Resumo: A microcefalia é uma condição neurológica que afeta o tamanho do perímetro cefálico. Nesta pesquisa qualitativa e descritiva, buscou-se avaliar como a mãe lida com o bebê real, identificando processos de reconstrução das idealizações maternas. Os instrumentos utilizados foram questionário sociodemográfico e entrevista semiestruturada gravada. A coleta foi realizada em três municípios do interior da Paraíba, nos domicílios de seis mães de microcéfalos com até um ano de idade. Os dados coletados no conteúdo emergente na fala das entrevistadas passaram pela análise temático categorial com suporte teórico psicanalítico. Foram identificadas nove categorias: a) reações ao diagnóstico; b) luto do bebê idealizado; c) elaboração do luto e mecanismos de enfrentamento; d) formas de lidar com o bebê e maternagem; e) dinâmica familiar após a descoberta da microcefalia; f) preconceito; g) atendimento focado em aspectos biológicos e físicos; h) acompanhamento psicológico e acolhimento; i) e suporte social. A mãe é abalada nos aspectos psicológicos e sociais. Os resultados mostram que a espiritualidade, o apoio familiar e de outras mães que vivenciam a mesma situação são formas de enfrentamento. O suporte social mais significativo é exercido pelas mães de outras crianças com microcefalia, com as quais as entrevistadas passaram a conviver em meio ao tratamento interdisciplinar dos filhos. O profissional de psicologia tem um papel fundamental na família que enfrenta a microcefalia, fortalecendo a maternagem, potencializando as forças da mãe para lidar com a desilusão e auxiliando-a na reorganização e adaptação a esse bebê com deficiências múltiplas, o que proporciona a reconstrução de suas idealizações.
\end{abstract}

Palavras-chave: Microcefalia, Zika Vírus, Relações Mãe-Filho, Idealização Materna.

\section{Being a Mother of a Child with Microcephaly: From Ideal to Real in the Zika Virus Congenital Syndrome (ZVCS)}

\begin{abstract}
Microcephaly is a neurological condition that affects child's head circumference. This qualitative descriptive research sought to evaluate how mothers of child with microcephaly deal with the real baby, identifying reconstruction processes of maternal idealizations. A sociodemographic questionnaire and a recorded semi-structured interview were conducted with the mothers of six babies born with microcephaly of up to one year of age from three municipalities of the countryside of Paraíba. With psychoanalytical theoretical support, data underwent categorical thematic analysis and resulted in nine categories: a) reactions to diagnosis; b) grief over the idealized baby; c) grief elaboration and coping mechanisms; d) ways of dealing with the baby and mothering bond; e) family dynamics after microcephaly diagnosis; f) prejudice; g) care focused on biological and physical aspects; h) psychological support and welcoming; and i) social support. The results indicate that mothers' psychological and social aspects are affected by the situation, with spirituality, family support, and contact with other mothers who experienced the same situation being coping strategies. According to the reports, the most significant social support was provided by the mothers of other children
\end{abstract}


with microcephaly, whom the interviewees got to know and spend time with during the interdisciplinary treatment of their children. Psychologists also offered significant support for the family facing microcephaly, helping to strengthen motherhood, empower the mother to cope with disillusionment, reorganize and adapt to this baby with multiple disabilities, and enable the mother to be rebuilt idealizations.

Keywords: Microcephaly, Zika Virus, Mother-Child Relationships, Maternal idealization.

\title{
Ser Madre de un Niño con Microcefalia: de lo Ideal a lo Real en Síndrome Congénito Asociado a Virus del Zika (SCZV)
}

\begin{abstract}
Resumen: La microcefalia es una afección neurológica que afecta el tamaño de la circunferencia de la cabeza. En esta investigación cualitativa y descriptiva, buscamos evaluar cómo la madre trata el bebé real, identificando los procesos de reconstrucción de idealizaciones maternas. Los instrumentos utilizados fueron el cuestionario sociodemográfico y la entrevista semiestructurada grabada. La recolección se realizó en tres municipios del interior de Paraíba (Brasil), en los hogares de seis madres de bebés con microcefalia de hasta un año de edad. Los datos recopilados en el discurso de las entrevistadas pasaron por el análisis temático categórico utilizando el apoyo teórico psicoanalítico. Se identificaron nueve categorías: a) reacciones al diagnóstico; b) duelo del bebé idealizado; c) elaboración del duelo y mecanismos de afrontamiento; d) formas de tratar el bebé y la maternidad; e) dinámica familiar después del descubrimiento de la microcefalia; f) prejuicio; g) atención centrada en aspectos biológicos y físicos; h) acompañamiento psicológico y acogedor; i) apoyo social. Los aspectos psicológicos y sociales de la madre son afectados. Los resultados muestran que las formas de afrontamiento son la espiritualidad, el apoyo familiar y otras madres que vivencian la misma situación. El apoyo social más significativo lo brindan las madres de otros niños con microcefalia, con quienes las entrevistadas comenzaron a convivir en medio del tratamiento interdisciplinario de sus hijos. El psicólogo desempeña un papel clave en la microcefalia que enfrenta la familia, incluido el fortalecimiento de la maternidad, el empoderamiento de las fuerzas de la madre para hacer frente a la desilusión, ayudarla a reorganizarse y adaptarse a este bebé con múltiples discapacidades, y permitir que sea reconstruida sus idealizaciones.
\end{abstract}

Palabras clave: Microcefalia, Zika Virus, Relaciones Madre-Hijo, Idealización materna.

Na última década, por várias razões - como a falta de eficácia das políticas públicas, o corte e má gestão de verbas públicas, o saneamento básico precário, o abastecimento irregular de água e as migrações -, a população brasileira tem sofrido com várias doenças ocasionadas por mosquitos, as arboviroses (Donalisio, Freitas, \& Zuben, 2017). Dentre os mosquitos causadores de doenças, se destaca o Aedes aegypti. Os mosquitos do gênero Aedes são os principais transmissores da dengue, chikungunya e zika em áreas urbanas e periurbanas (Avelino-Silva \& Ramos, 2017). Estas doenças, assim como a febre amarela, têm assustado a população, ceifado vidas e causado deficiências. "A modificação do ambiente por ações antrópicas, o crescimento urbano desordenado, o processo de globalização do intercâmbio internacional e as mudanças climáticas são alguns fatores que vêm facilitando a emergência e disseminação de doenças infecciosas humanas transmitidas por vetores" (Lima-Camara, 2016, p. 1).

Nesse contexto, destaca-se, desde 2015, a luta contra a microcefalia e a síndrome congênita do zika vírus (SCZV), quadro de deficiências múltiplas que traz medo e angústia à mãe e à familiares que recebem esse diagnóstico. A SCZV causa, dentre outras deficiências, a microcefalia, que afeta o tamanho da cabeça em relação ao considerado normal para a idade e raça da criança, além de provocar outras 
complicações de ordem visual, cognitiva, motora etc. A microcefalia pode ser primária (congênita) ou secundária (adquirida). Os danos do zika vírus (ZIKV) sobre o sistema nervoso central são múltiplos, sendo a microcefalia considerada apenas a ponta do iceberg. Em decorrência da agressão do sistema nervoso central pelo ZIKV, esta infecção pode provocar artrogripose, disfagia, surdez e comprometimento visual (Duarte et al., 2017).

Em 2015 surgiram muitos casos de microcefalia e com uma severidade maior se comparados aos casos clássicos antes do advento do zika vírus. De 2015 até dezembro de 2018 foram confirmados 2.819 casos de microcefalia e outras alterações do sistema nervoso, sugestivos de infecção congênita em todo o país. (Ministério da Saúde, 2018), com a região Nordeste concentrando o maior número de casos. Pode-se inferir, pela grande demanda de casos, que a microcefalia associada à SCZV foi algo novo, embora há alguns anos já se falasse sobre essa deficiência como ligada a outras síndromes.

Alguns autores apontam como uma das causas da microcefalia os agrotóxicos, assim como alimentos geneticamente modificados (Avelino, 2016). A complexidade do tema e a investigação de suas causas e consequências exigem uma abordagem interdisciplinar, visto que elas envolvem aspectos ético-políticos importantes e devem contemplar a dialética exclusão/ inclusão proposta por Sawaia (2010). Nela, a exclusão é vista como um descompromisso político com o sofrimento do outro a partir de um processo complexo e multifacetado que contempla dimensões materiais, políticas, relacionais e subjetivas, introduzindo, desse modo, as emoções como questão ético-política. Por isso, para compreender todos os aspectos subjacentes à SCZV, é necessária a contribuição de todas as áreas do conhecimento, inclusive da psicologia, tendo em vista que, no início da epidemia, as pesquisas divulgadas eram focadas nos aspectos biológicos $\mathrm{e}$ neurológicos, deixando em segundo plano os aspectos humanos, familiares, psicológicos e sociais.

Para melhor compreender a relação entre a mãe e o bebê com SCZV, é necessário esclarecer que o processo de filiação, bem como a construção da maternagem e paternagem, se inicia antes do nascimento do bebê, a partir da transmissão consciente e inconsciente da história infantil dos pais, de seus conflitos inconscientes e da relação com seus próprios pais. Assim sendo, o nascimento de um filho transforma definitivamente o psiquismo de cada um dos pais (Zornig, 2012).
A chegada de um novo membro, desejado e idealizado por toda a família ao longo da gestação, gera muitas mudanças, e não apenas na rotina familiar. Esse contexto de transformações com a chegada do bebê é potencializado quando a criança apresenta malformação congênita, o que pode levar ao medo, angústia e frustração dos pais, pois desejavam um filho perfeito. A mãe é cercada por um sentimento de medo de como a sociedade receberá seu filho e dos possíveis preconceitos que uma criança diferente poderá passar. Muitas vezes a expectativa é em torno de um ideal de normalidade.

Conforme Pereira (2008), "as deficiências, em especial as que estão estampadas no corpo, negam os padrões da aparência e da forma física, ferindo a 'harmonia' corporal" (p. 110). Nesse contexto, a sociedade estabelece um padrão de normalidade e quem está fora desses padrões estabelecidos é considerado anormal: "a deficiência, pensada apenas como uma anormalidade, é considerada abaixo, fora, aquém, sendo, por isso, considerada uma condição inferior" (Pereira, 2008, p. 112). Além do sofrimento de ter um filho que não corresponde ao ideal de normalidade imposto pela sociedade, a mãe que recebe o diagnóstico de malformação em seu filho é obrigada a mudar sua rotina, pois ele precisará de cuidados maiores com a saúde e sua vida poderá ficar em risco (Roecker, Mai, Baggio, Mazzola, \& Marcon, 2012). Tal dedicação exclusiva, sem os recursos de acessibilidade e tecnologia assistiva necessários para os cuidados da criança com deficiências múltiplas, acarreta danos à saúde física e mental da mãe, como distúrbios osteomioarticulares, dores incapacitantes, fadiga crônica, distúrbios do sono e problemas de saúde mental, comprometendo atividades de autocuidado e lazer da mãe. Isso tudo afeta sua autoestima e saúde mental (Dantas, Neves, Ribeiro, Brito, \& Batista, 2019), comprometendo as relações sociais e causando disfunções na família. Sendo assim, pode-se dizer que a família que recebe uma criança com malformação é aluída em sua organização, desempenho e individualidade, porque a família é uma unidade em que o que afeta um, atinge o outro (Franco \& Apolônio, 2002).

Diante da perda do filho idealizado, a mãe vivencia uma desilusão que culmina em um processo de luto (Franco, 2015). Conforme esclarecem Cavalcanti, Samczuk e Bonfim (2013), a ideia de luto não se limita apenas à morte, mas abarca também o enfrentamento das sucessivas perdas reais e simbólicas durante o 
desenvolvimento humano. Para Freud (1917), o luto é caracterizado por tristeza profunda e pelo afastamento de toda e qualquer atividade que não esteja ligada à pensamentos sobre o objeto perdido. Para o autor, quando há perturbação da autoestima do enlutado, esse processo trata da melancolia: "no luto, é o mundo que fica pobre e vazio; na melancolia, é o próprio ego" (Freud, 1917/1996, p. 251).

Diante do exposto, percebe-se que as mães de crianças com deficiência sofrem o luto de corpo presente, pois seus filhos idealizados não nasceram, embora posteriormente haja um renascimento desse sonho, uma reconstrução. Tomando a teoria psicanalítica como base, o quadro delas assemelha-se ao que Freud denominou melancolia, tendo em vista que há comprometimento da autoestima dessas mães, conforme várias pesquisas mostram (Campos et. al., 2018; Cordeiro et. al., 2018; Davi, 2018; Fernandes, 2018; Vale, 2018).

Os pais, que até então estavam seguros de seus papeis, têm de mudar de atitude. Na maioria dos casos, a mãe é a única a oferecer os devidos cuidados ao novo membro da família, o que pode levá-la a ficar sobrecarregada, com menos oportunidade de relaxar e de interagir com os demais membros da família (Prado, 2013). Para essas mães, pesa não só o lado emocional, mas também o modo como cuidarão de seus filhos sem a condição financeira adequada para a situação (Franco \& Apolônio, 2002; Roecker et al., 2012). Esse processo de luto pelo qual a mãe passa é único. Cada família encontra seu próprio meio de lidar com a perda, real ou simbólica, bem como com as mudanças que ela provoca (Silva, 2009).

A partir desse contexto, surgiu o questionamento de quais impactos as mães que recebem o diagnóstico dos filhos com essa deficiência podem estar vivenciando. O presente artigo teve o objetivo de avaliar, a partir de um diálogo interdisciplinar da psicanálise com as ciências sociais e da saúde, os impactos da microcefalia na dinâmica familiar a partir da percepção da mãe, verificando como a genitora lida com a deficiência e como se dá o processo de reconstrução das idealizações por ela.

\section{Método}

Este artigo é resultado de uma pesquisa qualitativa, em que foi explorada a fala dos participantes envolvidos, e descritiva, pois foram descritos e relacionados os dados obtidos através do questionário aplicado. As informações foram coletadas em 2016 em três cidades do interior da Paraíba, com seis mães de crianças com microcefalia com até um ano de idade, após aprovação do projeto pelo Comitê de Ética da Universidade Estadual da Paraíba, aprovado sob o CAAE no 60263416.40000.5187. Tal como as mães da pesquisa realizada por Vale (2018), elas compõem a primeira geração de familiares de crianças com microcefalia por ZIKV que conviveram inicialmente com "a escassez de informações sobre a epidemia e o adoecimento, a desorganização da rede de atenção à saúde e a exacerbada exploração do seu sofrimento pelas mídias sociais e programações de televisão" (p. 131).

Esta pesquisa foi realizada a partir de estudo de casos múltiplos. Um estudo de caso é uma investigação empírica que investiga um fenômeno contemporâneo dentro de seu contexto da vida real (Yin, 2015). Para Yin (2015), o estudo de casos múltiplos envolve a capacidade de conduzir seis ou dez estudos de caso que, no conjunto, fornecem uma base convincente para o conjunto inicial das proposições, seguindo uma lógica da replicação, não de amostragem.

Os instrumentos utilizados foram o questionário sociodemográfico e a entrevista semiestruturada gravada, que permitiu uma abertura maior para a emergência de outros conteúdos significativos que surgiam espontaneamente na fala das entrevistadas. A entrevista era composta de cinco questões abertas, que contemplaram as reações ao diagnóstico, a relação mãe-bebê, as dificuldades e idealizações, o suporte social, familiar e dos profissionais de saúde e os recursos de enfrentamento utilizados.

As informações colhidas passaram pelo processo de análise temático categorial, que consiste no processo através do qual os dados brutos, emergentes nas falas das entrevistadas, são sistematizados e agregados em unidades ou temas e analisados e apresentados em forma de descrições cursivas ou em forma de tabelas e gráficos, a partir de um olhar teórico específico (Oliveira, 2008). A ideia é categorizar o conteúdo das entrevistas para estabelecer uma estrutura temática de ideias em relação ao conteúdo emergente nas falas (Gibbs, 2009).

As categorias emergentes foram nove: a) reações ao diagnóstico; b) luto do bebê idealizado; c) elaboração do luto e mecanismos de enfrentamento; d) formas de lidar com o bebê e maternagem; e) dinâmica familiar após a descoberta da microcefalia; f) preconceito; g) atendimento focado em aspectos biológicos e físicos; h) acompanhamento psicológico e acolhimento; e i) suporte social. 


\section{Resultados e discussão}

As mães entrevistadas têm entre 19 e 36 anos, dentre as quais três tem ensino fundamental incompleto. As outras se dividem entre as que têm ensino médio incompleto, completo ou superior incompleto. Todas são casadas ou têm união estável e têm até dois filhos, conforme mostra a Tabela 1 . As entrevistas foram realizadas após o nascimento das crianças, no segundo semestre de 2016, no domicílio das entrevistadas, e seus filhos com microcefalia tinham até um ano de idade. Das mães entrevistadas, três moram com a família do marido (Mãe 3, Mãe 4 e Mãe 6), duas com a família de origem (Mãe 1 e Mãe 2) e apenas uma mora com o marido e a criança com SCZV (Mãe 5). Mesmo assim, todas relatam que o cuidado com a criança e o acompanhamento para tratamento é centralizado na figura materna.

Das seis entrevistadas, quatro moram em zona rural. Sobre tal contexto, Diniz (2016) vê a microcefalia como uma "epidemia em municípios rurais e entre gente pobre" (p. 135). Dentre as entrevistadas, prevalecem a pouca escolarização materna e o distanciamento dos grandes centros urbanos, onde é oferecido o acompanhamento às crianças com microcefalia.

\section{Tabela 1}

Dados sociodemográficos das entrevistadas.

\begin{tabular}{|c|c|c|c|c|c|c|c|}
\hline Entrevistada & Idade & $\begin{array}{l}\text { Número } \\
\text { de filhos }\end{array}$ & Escolaridade & Ocupação & $\begin{array}{l}\text { Renda } \\
\text { familiar }\end{array}$ & $\begin{array}{c}\text { Estado } \\
\text { civil }\end{array}$ & $\begin{array}{c}\text { Pessoas no } \\
\text { domicílio }\end{array}$ \\
\hline Mãe 1 & 32 & 2 & $\begin{array}{l}\text { Ensino médio } \\
\text { completo }\end{array}$ & Do lar & $\begin{array}{l}\text { Até } 1 \text { salário } \\
\text { mínimo }\end{array}$ & Casada & 4 \\
\hline Mãe 2 & 27 & 2 & $\begin{array}{l}\text { Ensino médio } \\
\text { incompleto }\end{array}$ & Do lar & $\begin{array}{l}1 \text { salário } \\
\text { mínimo }\end{array}$ & Casada & 5 \\
\hline Mãe 3 & 25 & 1 & $\begin{array}{l}\text { Ensino superior } \\
\text { incompleto }\end{array}$ & Estudante & $\begin{array}{l}2 \text { salários } \\
\text { mínimos }\end{array}$ & Casada & 6 \\
\hline Mãe 4 & 36 & 1 & $\begin{array}{c}\text { Ensino } \\
\text { Fundamental } \\
\text { incompleto }\end{array}$ & Do lar & $\begin{array}{l}2 \text { salários } \\
\text { mínimos }\end{array}$ & Casada & 4 \\
\hline Mãe 5 & 19 & 1 & $\begin{array}{c}\text { Ensino } \\
\text { fundamental } \\
\text { incompleto }\end{array}$ & Do lar & $\begin{array}{l}1 \text { salário } \\
\text { mínimo }\end{array}$ & Casada & 3 \\
\hline Mãe 6 & 27 & 2 & $\begin{array}{c}\text { Ensino } \\
\text { Fundamental } \\
\text { incompleto }\end{array}$ & Do lar & $\begin{array}{l}1 \text { salário } \\
\text { mínimo }\end{array}$ & $\begin{array}{l}\text { União } \\
\text { estável }\end{array}$ & 5 \\
\hline
\end{tabular}

\section{Reações ao diagnóstico}

A notícia da chegada de um filho gera um impacto no ambiente familiar. A mãe passa por momentos de ansiedade e depressão. A partir do terceiro trimestre da gravidez, a gestante geralmente passa a experimentar alguns pensamentos e sensações como as fobias relacionadas ao bebê nascer com alguma malformação, morrer no parto ou relacionadas até mesmo à morte intrauterina (Eizirik \& Bassols, 2013). Quando se fala em bebês com malformação, as mães, ao receberem a notícia, sentem "choque, medo, raiva, ansiedade, somatização, tristeza, pensamentos intrusivos, dentre outros" (Silva, 2009).
Esses sintomas foram observados nas falas das mães. A palavra ou a sensação de choque se repetiu oito vezes, tais como "foi um choque" (Mãe 1), "foi tipo uma surpresa ... que surpresa . . não poderia imaginar" (Mãe 6). A palavra "medo" foi repetida nas falas oito vezes: "sempre com aquele medo. Não era um medo de não aceitar era um medo assim de vê, era de ... era inexplicável"; "tenho medo dela não sobreviver" (Mãe 2). A ansiedade também está presente na fala delas, tais como em: "me senti nervosa"; "tinha muita ansiedade, fiquei muito nervosa"; "Minha ansiedade era demais" (Mãe 2). A tristeza foi observada na fala em nove ocorrências, como em: 
"A gente fica triste"; "chorei muito"; "Eu fiquei triste" (Mãe 3). A palavra "depressão" apareceu duas vezes nas falas de duas das mães: "entrei tipo em depressão" (Mãe 3); "quase que entrava em depressão" (Mãe 4). Os pensamentos intrusivos acerca da morte do bebê também foram relatados pelas mães: "Eu pensava em ele morrer" (Mãe 3); "passava mil coisas pela minha cabeça" (Mãe 2).

Outro ponto importante constatado nesta categoria foi relacionado à falta de informação sobre a deficiência, o que na ocasião fez com que as mães se preocupassem, deixando-as nervosas e ansiosas, justamente por não terem conhecimento sobre a microcefalia advinda do ZIKV no auge da epidemia. As informações transmitidas pela televisão e o preconceito das pessoas aumentou a preocupação das mães, tanto relacionadas ao nascimento do bebê, ao não saberem como seria seu filho, bem como ao futuro.

Não entendia quando recebi o diagnóstico (Mãe 1).

Eu conhecia a microcefalia genética, que o bebê pode andar, pode falar, tem suas debilitações, porém, poderia andar, fazer tudo. Só que a microcefalia proveniente da zika é diferente, eu fui pesquisar, pois é tudo muito novo. A gente não pode dizer se vai andar, vai falar, cada dia é uma conquista (Mãe 3).

Tinha, pelo que via na televisão pelos casos da região; mas a médica falou, perguntei algumas coisas, como ocasionou e ela explicou (Mãe 6).

Adentrando mais nas falas das mães, é possível analisar suas reações. Aquelas que, de alguma forma, tinham informação sobre a deficiência se mantiveram mais calmas no processo, como a Mãe 5: "Senti-me normal, agi normal, não fiquei tão abalada assim”. A forma que o diagnóstico é dado também é muito importante e pode acarretar aspectos emocionais negativos para mães e familiares, visto que, no momento do parto, a mãe encontra-se fragilizada, precisando de suporte, tanto da parte do marido como de seus familiares. A Mãe 6 relatou que recebeu a notícia de que seu filho tinha microcefalia na hora do parto, pouco antes do nascimento da criança, o que gerou um impacto.

A médica me chamou no cantinho e disse: 'Mãe, você sabe que seu filho tem problema?' Eu disse: 'não'. Aí ela disse: 'você bateu alguma ultrassom?' Eu disse 'sim. Ela disse: 'pois seu bebê tem esse probleminha', e disse que ele poderia chegar à óbito dentro de mim ou quando nascesse . . . E . . Foi um choque, viu?! Entrei em uma crise de choro... (Mãe 6).

A Mãe 6 segue relatando emocionada que o filho teve complicações após o parto, que estava inclusive internado no momento da entrevista na ocasião, a criança tinha pouco mais de três meses de vida. Ela também teve complicações no parto, que culminaram, segundo ela, em uma fratura na bacia, o que dificultou sua locomoção no acompanhamento da criança com SCZV durante a internação. Tal fato retrata a falta de humanização e de planejamento da notícia por parte de alguns profissionais. Conforme esclarecem Oliveira, Moreira, Lima e Melo (2018), quando a notícia não é transmitida de maneira adequada, amplia-se o sofrimento familiar e, consequentemente, aumenta a dificuldade em aceitar o filho. E os autores acrescentam: "algumas vezes, a postura distante e impessoal dos profissionais de saúde pode causar desespero e medo nos pais" (p. 5).

Tal postura não condiz com os preceitos da Política Nacional de Humanização, segundo a qual o acolhimento deve prezar pela resolutividade, ao pressupor que o profissional da equipe técnica deve escutar a queixa, os medos e as expectativas, identificar riscos e vulnerabilidades, acolhendo a avaliação do próprio usuário e se responsabilizando por dar uma resposta ao problema, conjugando as necessidades imediatas dos usuários com o cardápio de ofertas do serviço (Ministério da Saúde, 2014a).

No que se refere às gestantes e puérperas, o acolhimento é tido, antes de tudo, como uma postura a ser exercida por todas as equipes para melhor escutar e atender às necessidades singulares da mulher/ gestante. $\mathrm{O}$ desconhecimento e os mitos que rodeiam a gestação, o parto e o nascimento levam, muitas vezes, à insegurança e à preocupação da mulher e de seus familiares, especialmente quando envolve algo inicialmente desconhecido, como a SCZV. O acolhimento da mulher e acompanhante tem função fundamental na construção de um vínculo de confiança com os profissionais e serviços de saúde, o que favorece seu protagonismo, especialmente no momento do parto (Ministério da Saúde, 2014b).

A atenção pré-natal preconizada pela Política Nacional de Humanização favorece o vínculo e a avaliação de vulnerabilidades de acordo com o contexto 
social. Infelizmente a humanização com que as mães devem ser acolhidas não se evidenciou entre as que participaram da pesquisa, o que contribuiu para potencializar seu sofrimento de lidar com uma criança com deficiências múltiplas sem o suporte profissional adequado para atravessar o luto simbólico do filho idealizado.

Casellato (2015) afirma que, no momento do diagnóstico da malformação, a mulher carrega consigo a preocupação de ser mãe, advinda dos medos e expectativas associadas ao desenvolvimento, à saúde e, até mesmo o risco da morte de seu filho, como relata a Mãe 2:

O futuro só quem vai dizer pra mim é Deus. Mas eu tenho muita vontade que ela ande, que ela fale, que ela enxergue. A vontade é tão grande que observo ela dormir, vejo se ela tá respirando.... Eu já sonhei até com ela andando...

Nesse contexto, quando ocorre o diagnóstico de deficiências múltiplas e a necessidade de internação de tratamento intensivo neonatal (UTIN), há um sofrimento maior na mãe, como relatado pela Mãe 6: "meu filho tá internado, todos os dias vamos lá, um dia sou eu e outro é o pai". Ou seja, o momento que deveria ser de alegria é comprometido pela necessidade de internação do bebê e pelas limitações funcionais da malformação congênita que os pais vão descobrindo.

\section{Luto do bebê idealizado}

A descoberta da malformação da criança causa um impacto em toda a família. Quando se recebe o diagnóstico, há o processo de luto pelo "bebê ideal", ou seja, há a morte do sonho do filho perfeito e um impacto frente ao diagnóstico, como já mostrado na fala das mães. A constatação da malformação da criança gera profunda tristeza, medo do futuro, frustração e vergonha. É preciso vivenciar o processo de luto pelo filho que foi idealizado, para que seja possível estabelecer um vínculo de amor e cuidado com o filho que nasceu (Alves, 2012).

O processo do luto, real ou simbólico, em geral envolve a negação, raiva, barganha, depressão e aceitação (Kübler-Ross, 2017). A negação e a dificuldade em falar sobre o assunto ou até mesmo em verbalizar o nome microcefalia foram observadas em algumas falas:
Meu medo maior era de perder ela... não era nem tanto ... mas na cabeça da gente, a gente não quer entender. (Mãe 2).

Porque no momento eu não aceitei. (Mãe 3)

Meu bebê tinha né... esse....... (Mãe 6)

A barganha foi observada em falas como: "eu bati [morfológica] com a esperança dela não ter; aí eu fiquei na esperança, pedindo pra Deus que ela não tivesse" (Mãe 2) e a raiva em relatos como: "Eu ficava pensando: meu Deus, tantas meninas grávidas; meu Deus, por que só a minha? Por que isso só aconteceu com a minha? Eu ficava me perguntando, perguntava a Deus: Por que só aconteceu com a minha isso?" (Mãe 2).

A mãe passa pelo processo do luto do bebê ideal e, logo após a reconstrução do sonho e a confrontação com o filho real, que não é perfeito como ela sonhava, é através do amor, do cuidado da mãe e das várias formas de enfrentamento que ele passa a ser desejado e se torna aceito pela mãe. Os sentimentos de medo e angústia são superados pelo amor desenvolvido após a chegada do bebê.

\section{Elaboração do luto e mecanismos de enfrentamento}

Para Santos e Pereira-Martins (2016), cuidar de pessoas com deficiência é algo estressante para a família, especialmente quando são deficiências múltiplas, como no caso da SCZV. O estresse parental suscita mudanças no ajustamento familiar e estratégias são acionadas para facilitar o convívio com a pessoa com deficiência. As principais estratégias, segundo os autores, são: a busca de apoio social nos familiares e serviços profissionais, a união dos cônjuges e a busca de informação. $\mathrm{O}$ apoio do marido e da família, a espiritualidade, e a psicoterapia de grupo e individual foram relatados pelas mães entrevistadas como formas de enfrentamento e elaboração do luto.

Segundo Silva, Girão e Cunha (2016), a espiritualidade é utilizada como um conforto no enfrentamento da situação. Houve sete ocorrências aludindo a essa forma de enfrentamento entre as mães entrevistadas:

Graças a Deus ela está se desenvolvendo bem. Vou seguir em frente, se Deus quiser (Mãe 1).

Temos que aceitar. Foi assim que Deus permitiu (Mãe 6). 
Tinha uma colega do meu lado... Ela me deu bastante força, disse que o médico dos médicos era Deus, que Deus é quem dá e quem tira vida... (Mãe 6).

No processo de acolhimento da mãe por meio da escuta, as observações que visam conhecer a dinâmica familiar facilitam o processo de elaboração através do estímulo a pontos positivos na família. Silva (2009) reflete que há o tempo certo para cada tarefa dentro do processo de elaboração do luto, que é único e precisa ser construído pela família. Entende-se que, por ser único, o processo e a forma com que cada um o vivencia também são únicos. Assim, o tempo de elaboração dependerá da situação e do contexto no qual a mãe está inserida.

\section{Formas de lidar com o bebê e maternagem}

As formas de lidar com o bebê foram relatadas como preocupação da mãe, mesmo quando já tinham um filho, tendo em vista que a criança com microcefalia e com outras limitações funcionais em virtude do ZIKV requer um cuidado maior, assim como mais dedicação, adaptação e renúncias por parte da mãe. Conforme acrescentam Barros, Monteiro, Neves e Maciel (2017), o nascimento do filho com microcefalia muda a forma de ser mãe, uma vez que implica mais dedicação, empatia e sensibilidade. Sá et al. (2017) ressaltam o cansaço e a dificuldade das mães em administrar simultaneamente os afazeres domésticos, o cuidar da criança, do marido e dos outros filhos, e o lidar com os comentários da sociedade e com a exposição exagerada do assunto na mídia, especialmente na época do surto.

Na fala de duas das mães, se evidencia essa categoria: "mais estressante, pois ela vale por cinco crianças, pois o cuidado é maior” (Mãe 5); “. . . a única dificuldade que eu tenho é quando ela fica dodói; eu fico pensando: meu Deus, o que é que eu vou fazer, o que eu dou de remédio?"(Mãe 1). Estas falas mostram tanto a dificuldade no cuidado do bebê que as mães enfrentam, como também a renúncia que elas fazem para lidar com as questões relacionadas à criança, pois não encontram tempo hábil para interesses pessoais e atividades de lazer (Sá et al., 2017). Tal dado corrobora os levantados por Langaro e Pretto (2015) quando afirmam que, ao tornarem-se mães, a organização de suas vidas (rotinas, preocupações, objetivos, desejos) passa a voltar-se para o outro representado pelos filhos, ao mesmo tempo que as decisões no presente e sobre seus projetos de futuro cedem espaço para o desejo e demandas do outro.

A partir das observações na hora da entrevista e da fala das mães, percebeu-se que persiste a divisão sexual do trabalho no ambiente doméstico, tal como o papel tradicional da mulher voltado ao cuidado, sendo a mãe a principal cuidadora do filho. Ao longo da história, à mãe era, e ainda é, atribuído o cuidado do lar e dos filhos. Hoje acrescentou-se o lado profissional da mulher, que está não mais presa a um lar, mas é independente. A questão do gênero, sua identidade e o julgamento moral associado a ele permeiam o discurso e a prática dos casais (Fávero, 2010). Segundo a autora, essa persistência da responsabilidade da mulher em relação à esfera doméstica e ao cuidado ocorre porque os casais acabam legitimando os arranjos sociais fundamentados nas categorias e papeis de gênero, internalizados e reproduzidos no dia a dia. "Trata-se de uma atividade vista como parte dos papeis femininos e, portanto, visto como obrigação da mulher" (Fávero, 2010, p. 166). Bruschini complementa a reflexão sobre essa realidade ao pensar sobre o tempo gasto pela mulher nas tarefas domésticas: "o cuidado com os filhos é uma das atividades que mais consome o tempo de trabalho doméstico das mulheres" (2007, p. 49). Se essa criança tiver deficiência, demanda ainda mais tempo e dedicação materna.

A chegada do filho é um momento que foi se transformando ao longo da história. O nascimento do bebê e a maternagem, que está relacionada ao afeto, ao cuidado e ao carinho desenvolvidos pela mãe no vínculo com a criança, englobam aspectos que se transformam a partir do contexto histórico (Gradvohl, Osis, \& Makuch, 2014). Na Idade Média, a criança era vista como adulto em miniatura e a mãe era apenas a genitora, a que pariu; não havia um significado de cuidado e amor que hoje se encontra na figura da mãe. Atualmente a mulher se divide em vários papeis e a "santa mãezinha" renuncia muitas vezes aos demais, até mesmo ao de ser mulher, para dedicar-se ao filho (Fávero, 2010, p. 54).

As famílias que recebem um bebê com deficiência encontram várias dificuldades. Os problemas mais relatados pelas mães entrevistadas foram relacionadas ao transporte, citados oito vezes. Todas elas dependem do transporte para levar o filho para acompanhamento interdisciplinar e estimulação precoce em outro município, Campina Grande. 
O maior problema é o carro: tem que ligar, aí eles dizem 'já vai'; depois de uma hora, 'já tá indo'. Eles dizem que que já está agendado, certo, mas às vezes demora, às vezes não vem. . . Às vezes espero três horas; isso me deixa nervosa; se eu não tiver crédito, fico lá. Mandaram uma vez uma ambulância, eu passei mal, porque é fechada atrás, muito quente. Não tinha outro carro. Comecei a passar mal e não tinha ninguém para me socorrer (Mãe 2).

Quando não tem o transporte, meu marido vai me deixar ou eu pego um táxi; só não deixo de fazer o tratamento dele (Mãe 3).

Tive que entrar na justiça para conseguir o carro. Agora vem tudo normal (Mãe 4).

O problema maior é o transporte; às vezes tem que pegar o ônibus (Mãe 5).

O transporte às vezes demora, é alto pra subir. ... Quando não tem como ir no carro da prefeitura, a gente vai conforme nossos bolsos (Mãe 6).

O problema com o transporte emerge em várias pesquisas sobre a SCZV (Alves \& Fleischer, 2018; Canossa, Stelute, \& Cella, 2017; Freitas, Silva, Carvalho, Daltro, \& De Assis, 2019; Silvestre, 2018; Silva et. al., 2018), tendo em vista que a maior parte das crianças atingidas pela síndrome vive longe dos grandes centros onde são ofertados os serviços de estimulação precoce e reabilitação. Isso requer um sistema de transporte eficaz no município de origem para conseguir se locomover e fazer o tratamento, de modo que muitas vezes é necessária a judicialização para a garantia do direito, como feito pela Mãe 4.

O choro do bebê foi relatado como fator estressor, mas foi atenuado a partir da utilização de ansiolítico pelas crianças, restabelecendo o equilíbrio no ambiente familiar: "No começo, quando ela era novinha, chorava muito e a gente não entendia o que era; ninguém dormia; cada um pegava ela e a gente não sabia o que era. Agora ela toma calmante, tá bem" (Mãe 5). As renúncias laborais em prol do cuidado com a criança e o ônus financeiro para suprir as necessidades diversas da criança não atendidas pelo Estado, a exemplo das falhas de transporte, foram aludidos como dificuldades.

\section{Dinâmica familiar após a descoberta da microcefalia}

Quando a família sabe que a criança tem microcefalia, de um momento para o outro, todos passam a conviver com uma criança que não condiz com a figura desejada. Surge um grande sentimento de perda e de sonhos desfeitos, o que altera toda a dinâmica familiar e necessita de adaptação por todos (Prado, 2013). Para Eizirik e Bassols (2013), o pai é de grande importância no processo gestacional em todos os momentos, especialmente nesse contexto, o que corrobora com a fala das mães ao falar sobre a posição do pai no processo.

Ele estava comigo, falou: vamos ter calma! (Mãe 1).

Ele ficou com a cabeça baixa, mas disse: 'seja o que Deus quiser; do jeitinho que ela vier será bem-vinda'; ele nunca me deixou abater, ele tinha um pensamento diferente do meu, ele tinha o pensamento que ia dá tudo certo (Mãe 2).

Meu marido não ligou, minha família todinha aceitou... Foi muito amor com ela... (Mãe 4).

Ele ficou muito abalado, chorou muito... A vó também. Os familiares ficaram muito abalados (Mãe 5).

Ele aceitou... ahaaaa... com certeza a gente ama nosso menino... Ele é um pai maravilhoso (Mãe 6).

As falas acima mostram o quanto é importante o pai no processo da gestação, no parto e no puerpério, ao ajudar a mãe a controlar a dor e a ansiedade ao assumir uma posição de afeto e de carinho. Ao saber da notícia da deficiência do filho, segundo as mães, os pais demonstraram tristeza, choque e ansiedade. Foi observada também a postura de confiança e o apoio do pai às mães. A forma como os pais reagem diante da deficiência do filho influencia muito no desenvolvimento dele, conforme ressalta Prado (2013). Essas posições realçam a importância do ajustamento familiar para o desenvolvimento da criança com microcefalia, além de quebrarem o paradigma de que os pais devem ser a "fortaleza" em que não deve haver choro. Observou-se a quebra do silêncio por parte dos pais na presente pesquisa e o quanto eles exercem seu papel de forma ativa e amorosa para com suas famílias.

No entanto, a epidemia do ZIKV acabou agravando um problema do país: o abandono paterno. 
Muitas vezes o abandono por parte do genitor nos casos de SCZV acontece antes mesmo do nascimento da criança, logo após seu diagnóstico (Nascimento, 2018). Em parte significativa da amostra de Davi (2018), a descoberta da microcefalia na criança já na gestação promoveu uma ruptura nas relações entre os pais dessas crianças, não havendo por parte deles qualquer apoio no cuidado com as mães após o nascimento, fragilizando e sobrecarregando-as ainda mais. Essa realidade vulnerabilizou e amedrontou inclusive as mães que não foram abandonadas e que acabaram por comemorar o fato de o marido prosseguir com elas mesmo após o diagnóstico da malformação, mesmo que baseados num processo de negação: "Ele poderia ter me deixado, mas não... . . A todo o momento me deu suporte. Ele ficou triste, mas disse que tinha certeza que poderia nascer sem a microcefalia" (Mãe 3).

O apoio familiar também é de extrema importância para o enfrentamento. Foram relatadas pelas mães as reações quando receberam a notícia. O choque e a tristeza podem ser observados nas falas, mas também pode se perceber o acolhimento: "Foi uma surpresa para todo mundo; se sentiram muito chocados" (Mãe 1); "A família ficou triste" (Mãe 2); "A família teve aquele impacto, mas depois aceitou” (Mãe 5).

$\mathrm{Na}$ fala das mães, percebe-se que o apoio dos familiares ocorre mais no sentido da aceitação e do acolhimento, mas não no compartilhamento da responsabilidade do cuidado com a criança. Por medo do estigma e da superexposição, as mães relataram que, logo após o diagnóstico, se isolaram e tentaram restringir ao meio familiar a informação de que a criança tinha a SCZV.

\section{Preconceito}

O preconceito das pessoas acerca da microcefalia é percebido na fala das mães. Antes mesmo do filho nascer, elas já sentiam medo pelo futuro deles. Conforme Valle e Connor (2014), em geral, atribui-se às pessoas com deficiência um status de segunda classe, sendo consideradas inferiores por seus pares sem deficiência. Esse estigma foi muito acentuado no que se refere às crianças com SCZV. Não houve empatia e acolhimento adequados por parte da comunidade com o momento de sofrimento de muitas dificuldades pelo qual as mães estavam passando. Tal insensibilidade fez com que elas não quisessem compartilhar esse momento com as pessoas, o que, segundo Balieiro e Cerveny (2013), é fator de risco do processo de adoecimento.
Eu não falei pra ninguém. Eu pensei assim: 'se no início, só em ver as reportagens, elas já xingam, começam a falar coisas, por que éque eu vou falar?' Muitas pessoas tinham preconceito, chamava de 'cara de sapo' (Mãe 1).

Elas são tão feia, que parece com 'um sapo'(Mãe 2).

Ninguém chega pra mim para perguntar o que ela tem ou o que ela não tem... Ficam só olhando de longe (Mãe 4).

Muitas pessoas não queriam ver ela porque era um bebê, mas sim para ver o tamanho da cabeça, pra saber como é, malformação, essas coisas. As pessoas que olham às vezes pensam que é uma doença, mas eu não ligo. Ficam perguntando, com medo, não entendem... (Mãe 5).

A hipervisibilidade da SCZV na época da epidemia, o assédio da imprensa e dos cientistas, a curiosidade das pessoas e o medo do estigma e do olhar de reprovação social fizeram com que muitas mães se isolassem socialmente, o que acabou contribuindo para uma maior vulnerabilidade social delas e das famílias. Para Pereira (2008), "pensar a deficiência como uma diferença requer que se considere essa condição, entre outros aspectos, a partir do impacto que ela causa no observador" (p. 107). Como corroboram Oliveira et. al. (2018), o impacto do diagnóstico da SCZV, a necessidade de adaptação à nova situação e o estigma social podem produzir sobrecargas, conflitos e medo.

\section{Atendimento focado em aspectos biológicos e físicos}

Apesar da importância dos aspectos sociais e familiares no desenvolvimento da criança com microcefalia, as pesquisas inicialmente focavam nos aspectos biológicos e funcionais. Tal característica acaba se refletindo em falas como: “... meu maior suporte, lá foi onde eu pude fazer os exames necessários . . fisioterapeuta ..." (Mãe 1); “só não deixo de fazer o tratamento dele" (Mãe 3). O ideal de normalidade é percebido também através do foco nos aspectos físicos e funcionais e das comparações com doença, o que demonstra ainda a falta de informação do que é deficiência.

Eu tenho ela como um bebê normal (Mãe 1).

As pessoas chegavam perto de mim e diziam que ela tinha uma doença. Teve uma mulher que eu 
tava tentando dá a menina pra ela segurar e ela com medo (Mãe 2).

As pessoas que olham às vezes pensam que é uma doença, mas eu não ligo não, ficam pensando perguntando, com medo, não entende ... (Mãe 5).

Segundo Pereira (2008), "a noção de normalidade produz um corpo ideal e, paralelamente, rejeita o diferente, o desigual, rejeita aqueles que não cabem nesse modelo idealizado" (p. 126). Para o autor, o corpo idealizado, construído sobre os alicerces do padrão de normalidade, apresenta uma diferença positiva, desejável, "uma diferença que resulta em status” (Pereira, 2008, p. 131). Sendo assim, esse ideal de normalidade acaba por naturalizar e banalizar o preconceito e a discriminação, como acontece com as crianças com SCZV, e que são potencializados pela falta de informação e pela excessiva exposição midiática no período da epidemia.

\section{Acompanhamento psicológico e acolhimento}

O profissional de psicologia é de fundamental importância no momento de acolhimento da pessoa de forma empática, de modo que ele deva compreender ser este momento único que só a pessoa que o vivencia compreende o que está sentindo. $\mathrm{O}$ acolhimento, as dúvidas, as preocupações (sejam elas exageradas ou reais), as angústias e outras questões relacionadas ao desenvolvimento e ao cuidado do bebê são de grande importância para o enfrentamento e para a elaboração do luto. A busca constante de conhecimento dos temas relacionados à maternagem e aos aspectos médicos relacionados às limitações funcionais da criança com SCZV, decodificando-os de forma compreensível para as famílias e aliviando sua ansiedade é uma forma de estar apto no auxílio às mães e familiares. As mães retratam um pouco dessa função estratégica do profissional de psicologia no diagnóstico e acompanhamento à essas famílias:

Fui acompanhada. Foi bom, pois ela me esclareceu, tem o atendimento com a psicóloga (Mãe 1).

Antes individual e agora em grupo e individual (Mãe 2).

Desde que ela nasceu e ainda sou [acompanhada por profissional]. Ela dá muito conselho, ajuda muito (Mãe 5).
A partir das falas citadas, percebe-se a importância do acompanhamento psicológico na busca por esclarecimentos do que acontecia durante a epidemia. Bem como afirmam Osório e Valle (2009), é preciso se colocar à disposição para responder as perguntas que favoreçam o entendimento do que as mães estão vivenciando.

No momento anterior ao nascimento do bebê, o profissional de psicologia pode trabalhar de forma a esclarecer dúvidas e a focar no luto antecipatório, ajudando as mães a ressignificarem suas idealizações. O trabalho de acolhimento e de suporte não deve ser realizado apenas pelos profissionais da área de psicologia, mas deve envolver toda a equipe de saúde (Eizirik \& Bassols, 2013; Silva, 2009).

Osório e Valle (2009) discutem a "quebra do silêncio", que é essencial no processo desde a descoberta da deficiência do filho até o nascimento e a vivência com ele. Esse momento é facilitado pelo trabalho do acompanhamento psicológico, seja em grupo, seja individual. A função do profissional de psicologia é promover um espaço de acolhimento à mãe e estimular o seu potencial no relacionamento com o bebê e no enfrentamento em todos os âmbitos.

\section{Suporte social}

O suporte social é muito importante para fortalecer a mãe e a família de crianças com microcefalia. Prado (2013) ressalta que essas famílias precisam do apoio de toda rede social para que possam lidar melhor com a realidade inesperada. Com o apoio da rede social, especialmente da família de origem, essas mães estarão mais capacitadas e qualificadas para suprir seu papel fundamental. Mas, devido à escassez de informações precisas no início da epidemia e ao estigma da SCZV, associados à pouca escolaridade da família de origem, algumas mães não tiveram o suporte que necessitavam para enfrentar as dificuldades de ter uma criança com malformação, vivenciando um processo de culpabilização: "A minha família mesmo, meu pai, minha mãe, se sentiram muito chocados, por morar no sítio, tudo para eles é novidade, como foi novidade para todo mundo. Mas tivemos que aceitar. Não foi porque a gente quis, né?" (Mãe 1).

A partir do discurso das mães entrevistadas, evidenciou-se que uma das formas de enfrentamento foi relacionada à interação permeada pelas trocas de informações e experiências, pelas demonstrações de empatia e de solidariedade com outras mães de 
filhos com microcefalia, dados similares aos relatados por Barros et al. (2017): "a amizade de mães que tem crianças com mães que tem crianças com a SCZV destacam-se como uma das principais estratégias de enfrentamento" (p. 55).

A importância da rede de mães de crianças com microcefalia evidencia-se na fala da Mãe 1: "Entre mães, a gente conversa muito, troca muita ideia, uma ajuda a outra, isso tem sido de muito apoio". Para Santos e Pereira-Martins (2016), a busca de apoio social é altamente associada ao fortalecimento da resiliência familiar. Conforme Fiamenghi Junior e Messa (2007), é de fundamental importância compartilhar experiências com pessoas que também estão passando pela mesma situação. Pedroso e Félix corroboram a importância dessa rede de apoio: "o contato com grupo de iguais fora do meio familiar oferece uma troca de experiências que resultam em efeitos emocionais e comportamentos positivos, como conforto e preparo para enfrentar as dificuldades" (Pedroso \& Félix, citado por Oliveira \& Sá, 2017, p. 515).

Como as informações iniciais acerca da microcefalia em virtude do ZIKV eram incertas e efêmeras quando houve o surto em 2015, visto que essa condição ainda estava em investigação, as mães buscaram estratégias informais para compreender melhor a situação vivenciada por elas e suas famílias. Elas formaram associações, criaram grupos de WhatsApp, blogs e páginas do Facebook, promovendo a ampliação de suas relações ou da própria rede (Scott et. al., 2017).

Conforme Valle e Connor (2014), o ativismo é parte integrante da cultura das deficiências, ao celebrar a vida de pessoas com deficiência em seu próprio movimento como protagonistas que partem das margens da sociedade rumo ao seu centro, reafirmando as deficiências como uma parte natural da diversidade humana. No contexto da SCZV, percebeu-se a emergência de significativo ativismo digital, que coloca a internet e as mídias sociais como ferramentas eficazes para o engajamento cívico e político, possibilitando articulações sociais e engajamento ético-político por meio de "um espaço virtual para ações de planejamento, organização e execução de protestos" (Vasconcelos Filho \& Coutinho, 2017, p. 10).

$\mathrm{O}$ ativismo digital das mães de criança com SCZV é um espaço de articulação e de resistência importante, que promove conquistas sociais e políticas através de suas mobilizações, chegando a promover o que Sawaia (2010) chama de felicidade ético-política, que ocorre "quando se ultrapassa a prática do individualismo e do corporativismo para abrir-se à humanidade" (p. 107), rechaçando e combatendo a insensibilidade ao sofrimento do outro. Para Fleischer (2017), a televisão e, principalmente, as mídias sociais são ferramentas importantes para compartilhar informações, facilitar a compreensão dos processos de cuidado relacionados à SCZV, empoderando essas mães e estimulando o autocuidado e a funcionalidade familiar.

Diniz (2016) acrescenta que essa articulação entre as mães de crianças com microcefalia se constituiu como um espaço de produção de uma ciência doméstica do cuidado, que evoluiu em paralelo às pesquisas científicas, focadas nos aspectos físicos, biológicos e funcionais. Silva, Matos e Quadros (2017) chamaram essa biologização da microcefalia e da SCZV de modelo mosquitocêntrico, visto que grande parte dos investimentos e do empenho tecnológico foi destinada ao estudo do mosquito, deixando de lado as pessoas e as famílias que vivenciam essa realidade. Ainda não se priorizava o impacto social e emocional, bem como a carga financeira das famílias e o despreparo das equipes de saúde para avaliar e instituir métodos eficazes de intervenção ao longo do tempo (Brunoni et al., 2016).

Durante a epidemia, a ênfase, inclusive midiática, foi no acompanhamento das pesquisas, silenciando as condições sociais, econômicas e políticas que permitem a reprodução do Aedes e a ocorrência das doenças e deficiências dele advindas, e pouco se falava sobre o fato de a microcefalia ter atingido principalmente bebês de mulheres pobres do Nordeste brasileiro (Cardoso, Câmara, \& Fiorito, 2017). Como complementam Zago e Pimentel (2017), "todo esquecimento político vem acompanhado de um esquecimento midiático" (p. 171). Foi o que aconteceu após a declaração do fim da epidemia de zika vírus: essas famílias e seus dramas diários foram esquecidos pela mídia, pela sociedade e pelo poder público. Após seis anos do surto de zika vírus no Brasil, essas crianças com a SCZV ainda existem, assim como suas famílias, mas foram progressivamente invisibilizadas.

\section{Considerações finais}

Ninguém espera um filho com malformação e, quando essa notícia chega, toda a família é impactada. Esse processo é sentido pela mãe de forma mais ativa, justamente por ela ser a genitora e ainda a principal cuidadora da criança. Ao passar pelos processos de idealização do filho perfeito, o diagnóstico chega 
como um "balde de água fria", levando embora seus sonhos e projetos para o futuro do filho. Na fala das mães, percebe-se que a busca pelo filho dito "normal" é trazida como algo construído historicamente no contexto social. As preocupações maternas são diversas acerca do futuro da criança. Entre elas estão o preconceito e a sobrevivência dos filhos. O nascimento de uma criança com microcefalia ocasionada pela SCZV é um momento marcado pela incerteza e insegurança das mães e dos familiares que recebem um filho com essa malformação congênita.

As renúncias por parte das mães são muitas. Os papéis sociais de esposa, de mulher do lar e de profissional, entre outros se mostram bastante comprometidos. Muitas delas deixam em segundo plano as atividades domésticas e o emprego para dedicar-se exclusivamente aos cuidados com o filho. A partir da fala das mães, percebe-se que é o amor, o carinho e o tornar-se mãe, juntamente ao suporte social e familiar, que motivam a genitora a prestar esse cuidado atencioso, muito embora desgastante, enfrentado todos os dias, com o desejo de verem seus filhos se desenvolverem nos aspectos biopsicossociais.

As mães, na presente pesquisa, não desistiram e nem foram abandonadas pelos cônjuges por terem um filho com microcefalia. As formas de enfrentamento e de reconstrução do sonho se deram pelo apoio do cônjuge, dos familiares e de mães que também estavam passando pelo mesmo processo. A espiritualidade e a psicoterapia foram trazidas nas falas como um meio de adaptação e de reorganização mental e familiar. As entrevistadas externalizaram que houve a reconstrução do sonho e o filho, diferente do idealizado, se torna o filho desejado, perfeito aos olhos da mãe.

A informação relacionada às limitações funcionais, aos prognósticos e à expectativa de vida da criança com SCZV eram escassas no auge da epidemia, o que contribuía para aumentar a ansiedade e as incertezas dessas famílias. Os estudos sobre microcefalia e SCZV ainda eram recentes e incipientes quando as entrevistas foram realizadas e priorizavam os aspectos médicos e funcionais, tornando invisível o sofrimento e as dificuldades enfrentadas por essas famílias.

Devido à falta de informações precisas na ocasião e de humanização por parte de alguns profissionais, as mães declararam ter se sentido impactadas, chocadas, tristes e, até mesmo, com sintomas depressivos, por não entenderem o que realmente seu filho tinha. Esse processo de informação e de acolhimento deve ocorrer desde o diagnóstico do ZIKV até o momento de a mãe procurar o profissional. O profissional de psicologia tem que exercer o papel de apoio e estar pronto para fornecer informações à mãe e familiares, assim como precisa acolher o sofrimento, contribuir para ressignificá-lo e auxiliar a decodificar informações médicas, técnicas e de saúde, de forma que a família as entenda, diminuindo a ansiedade e o choque no momento do diagnóstico e durante o processo de acompanhamento interdisciplinar. Tais atribuições assumidas pelos profissionais de psicologia não eximem as demais categorias profissionais de oferecer uma escuta ativa e empática, assim como um ambiente acolhedor a essas mães.

O profissional de psicologia que atua nessa área precisa de uma formação continuada voltada para a compreensão desses aspectos. O luto e seus processos devem ser entendidos de forma personalizada, considerando a subjetividade dos sujeitos e a dinâmica familiar e com o devido acolhimento, de forma a facilitar o enfrentamento. Esse processo é importante para estimular a adaptação ao bebê com deficiências múltiplas da melhor forma possível. Tais aspectos devem ser contemplados não só na prática psicológica, como também nas pesquisas sobre o tema. Para trabalhar com mães e famílias com filhos com microcefalia, é preciso a realização de capacitação para os profissionais de saúde e educação, o que só ocorreu depois. Esse é um campo com uma grande demanda, inclusive para a psicologia. Apesar de ter sido decretado fim da epidemia em 11 de maio de 2017, 18 meses após o país decretar emergência em saúde pública (Ministério da Saúde, 2017), as necessidades e desafios das famílias atingidas pela SCZV persistem e vão muito além do acompanhamento médico e fisioterapêutico. Os grupos terapêuticos, a psicoterapia individual, a transmissão de informações atualizadas relacionadas ao tema e o suporte social, familiar e financeiro são meios que auxiliam a mãe nesse momento.

Diante do que foi coletado na pesquisa, percebe-se muitos temas emergentes para investigações longitudinais que possam contribuir para o aperfeiçoamento e humanização das práticas profissionais, como: o profissional de psicologia e sua atuação em casos de SCZV; o pai e o cuidado do filho com microcefalia, irmãos de crianças com microcefalia; os profissionais de saúde frente ao quadro de SCZV; as vivências da gestação do contexto do ZIKV; as mudanças de comportamento após as doenças causadas por arboviroses; 
a saúde mental em famílias com crianças com microcefalia; a importância de acompanhamento psicológico na gestação; a invisibilidade das crianças com SCZV após o fim da epidemia; o ativismo digital, social e político das "mães de micro"; a situação atual das famílias atingidas pela SCZV; a adesão ao tratamento da SCZV por parte das famílias; as disfunções em famílias acometidas pela SCZV; e a inclusão educacional das crianças com SCZV.

Conclui-se assim que a mãe, como a principal cuidadora de seu filho, também precisa de atenção em seus vários aspectos e que muito ainda se tem a fazer em se tratando de microcefalia causada pela SCZV. Serviços de atendimento às mães que melhorem sua saúde física e mental e que restabeleçam sua autoestima e qualidade de vida devem ser pensados enquanto políticas públicas de saúde, de forma a proporcionar um momento de descanso e de valorização dessas mães, assim como políticas públicas eficazes que assegurem os direitos e a cidadania dessas famílias. Para finalizar e resumir o momento das mães entrevistadas, a fala da Mãe 2 sintetiza o significado da maternagem positiva: "Quando eu olho pra ela, cada vez que olho, o amor cresce mais".

\section{Referências}

Alves, E. G. R. (2012). A morte do filho idealizado. O Mundo da Saúde, 36(1), 9097.

Alves, R. L. C, \& Fleischer, S. (2018). 'O que adianta conhecer muita gente e no fim das contas estar sempre só?': Desafios da maternidade em tempos de Síndrome Congênita do Zika Vírus. Anthropológicas, 29(2), 627. https://doi.org/10.51359/2525-5223.2018.239316

Avelino, M. A. (2016). Desenvolvimento cerebral em risco. Psique, 122, 14.

Avelino-Silva, V. I., \& Ramos, J. F. (2017) Arboviroses e políticas públicas no Brasil. Ciências em Saúde, 7(3), 12. https://doi.org/10.21876/rcsfmit.v7i3.675

Balieiro, C. R. B., \& Cerveny, C. M. O. (2013). Família e doença. In C. M. O. Cerveny (Org.), Família e...: comunicação, divórcio, mudança, resiliência, deficiência, lei, bioética, doença, religião e drogadição (pp. 147161). Casa do Psicólogo.

Barros, S. M. M., Monteiro, P. A. L., Neves, M. B., \& Maciel, G. T. S. (2017). Fortalecendo a rede de apoio de mães no contexto da síndrome congênita do vírus Zika: relatos de uma intervenção psicossocial e sistêmica. Nova Perspectiva Sistêmica, 26(58), 3859.

Brunoni, D., Blascovi-Assis, S. M., Osório, A. A. C., Seabra, A. G., Amato, C. A. H., Teixeira, M. C. T. V., Rocha, M. M., \& Carreiro, L. R. R. (2016). Microcefalia e outras manifestações relacionadas ao vírus Zika: impacto nas crianças, nas famílias e nas equipes de saúde. Ciência \& Saúde Coletiva, 21(10), 32973302. https://doi.org/ $10.1590 / 1413-812320152110.16832016$

Bruschini, C. (2007). Trabalho doméstico: inatividade econômica ou trabalho não remunerado? In C. Araújo, F. Picanço, \& C. Scalon (Orgs.), Novas conciliações e antigas tensões? Gênero, família e trabalho em perspectiva comparada (pp. 2158). Edusc.

Campos, M. M. M. S., Sousa, T. C., Teixeira, G. P., Chaves, K. Y. S., Araújo, M. V. U. M, \& Sousa, M. R. (2018). Desafios e perspectivas de mães de crianças com microcefalia pelo vírus Zika. Revista Rene, 19, e32839. https://doi.org/ $10.15253 / 2175-6783.20181932839$

Canossa, G. C., Stelute, L., \& Cella, D. (2017). Zika Vírus: análise, discussões e impactos no Brasil. Revista Interface Tecnológica, 14(1), 311331.

Cardoso, J., Câmara, J., \& Fiorito, P. (2017). Zika e microcefalia no Fantástico e Jornal Nacional. 40o Congresso Brasileiro de Ciências da Comunicação, Curitiba, PR, Brasil. http://portalintercom.org.br/anais/nacional2017/ resumos/R12-3305-1.pdf

Casellato, G. (2015). Em busca da empatia. Suporte psicológico ao luto não reconhecido. Summus.

Castro, R. (2017, 12 de maio). Ministério da Saúde declara fim da Emergência Nacional para Zika e microcefalia. Fundação Oswaldo Cruz. https://rededengue.fiocruz.br/noticias/580-ministerio-da-saude-declara-fim-daemergencia-nacional-para-zika-e-microcefalia

Cordeiro, E. L., Silva, T. M., Silva, L. S. R., Veloso, A. C. F., Pimentel, R. V. T., Cabral, M. M. O., \& Silva, C. M. (2018). A humanização na assistência ao parto e ao nascimento. Revista Enfermagem UFPE Online, 12(18), 2154-2162. 
Dantas, K. O., Neves, R. F., Ribeiro, K. S. Q. S., Brito, G. E. G., \& Batista, M. C. (2019). Repercussões do nascimento e do cuidado de crianças com deficiência múltipla na família: uma metassíntese qualitativa. Cadernos de Saúde Pública, 35(6), e00157918. https://doi.org/10.1590/0102-311X00157918

Davi, S. S. C. (2018). Significado e repercussões da Síndrome Congênita do Zika Vírus sobre as práticas de cuidados maternos em saúde no sertão da Paraíba [dissertação de mestrado, Universidade Católica de Santos]. TEDE UniSantos. http://biblioteca.unisantos.br:8181/bitstream/tede/4761/1/Simone\%20da\%20Silva\%20Cordeiro\%20Davi.pdf

Diniz, D. (2016). Zika: do sertão nordestino à ameaça global. Civilização Brasileira.

Donalisio, M. R., Freitas, A. R. R., \& Zuben, A. P. B. V. (2017). Arboviroses emergentes no Brasil: desafios para a clínica e implicações para a saúde pública. Revista de Saúde Pública, 51, 30. https://doi.org/10.1590/ s1518-8787.2017051006889

Duarte, G., Moron, A. F., Timerman, A., Fernandes, C. E., Mariani Neto, C., Almeida Filho, G. L., Werner, H., Jr., Santo, H. F. B. E., Steibel, J. A. P., Bortoletti Filho, J., Andrade, J. B. B., Burlá, M., Sá, M. F. S., Busso, N. E., Giraldo, P. C., Sá, R. A. M., Passini, R., Jr., Mattar, R., \& Francisco, R. P. V. (2017). Zika Virus infection in pregnant women and microcephaly.RevistaBrasileiradeGinecologiaeObstetrícia,39(5),235248.https://doi.org/10.1055/s-0037-1603450

Eizirik, C. L., \& Bassols, A. M. S. (2013). O ciclo da vida humana: uma perspectiva psicodinâmica (2a ed.). Artmed.

Favéro, M. H. (2010). Psicologia do gênero: Psicobiografia, sociocultura e transformações. Editora da UFPR.

Fernandes, C. C. F. (2018). Qualidade de vida de mães de crianças com microcefalia. [dissertação de mestrado, Universidade Federal de Sergipe]. Biblioteca Digital Brasileira de Teses e Dissertações. https://bdtd.ibict.br/ vufind/Record/UFS-2_8a3fd2b01al45370b3775e8e091d67ac

Fiamenghi G. A., Jr., \& Messa, A. A. (2007). Pais, filhos e deficiência: Estudos sobre as relações familiares. Psicologia: Ciência e Profissão, 27(2), 236245. https://doi.org/10.1590/S1414-98932007000200006

Fleischer, S. (2017). Segurar, caminhar e falar: notas etnográficas sobre a experiência de uma "mãe de micro" no Recife/PE. Cadernos de Gênero e Diversidade, 3(2), 93112. http://doi.org/10.9771/cgd.v3i2.21983

Franco, V. (2015). Paixão-dor-paixão: Pathos, luto e melancolia no nascimento da criança com deficiência. Revista Latinoamericana de Psicopatologia Fundamental, 18(2), 204-220. https://doi.org/ 10.1590/1415-4714.2015v18n2p204.2

Franco, V., \& Apolônio, A. M. (2002). Desenvolvimento, resiliência e necessidades das famílias com crianças deficientes. Revista Ciência Psicológica, (8), 4054.

Freitas. J. L., Silva Jr., R. A., Carvalho, A. G., Daltro, M. C. S. L., \& De Assis, S. C. (2019). Itinerário terapêutico de crianças com síndrome congênita zika vírus. Temas em Saúde, 19(1), 251263.

Freud, S. (1996). Luto e melancolia (Edição Standard Brasileira das Obras Psicológicas Completas de Sigmund Freud, Vol. XIV). Imago. (Trabalho original publicado em 1917)

Gibbs, G. (2009). Análise de dados qualitativos. Artmed.

Gradvohl, S. M. O., Osis, M. J. D., \& Makuch, M. Y. (2014). Maternidade e formas de maternagem desde a idade média à atualidade. Pensando Famílias, 18(1), 5562.

Kübler-Ross, E. (2017). Sobre a morte e o morrer (10a ed). Martins Fontes.

Langaro, F., \& Pretto, Z. (2015). Experiências de parentalidade como fatores geradores de sofrimento em mulheres. Fractal: Revista de Psicologia, 27(2), 130138. https://doi.org/10.1590/1984-0292/453

Lima-Camara, T. N. (2016). Arboviroses emergentes e novos desafios para a saúde pública no Brasil. Revista de Saúde Pública, 50, 36. https://doi.org/10.1590/S1518-8787.2016050006791

Ministério da Saúde. (2014a). Humanização do parto e do nascimento (Cadernos HumanizaSUS, v. 4). Universidade EstadualdoCeará.http://www.redehumanizasus.net/sites/default/files/caderno_humanizasus_v4_humanizacao_ parto.pdf

Ministério da Saúde. (2014b). Manual de acolhimento e classificação de risco em obstetrícia. http://bvsms.saude. gov.br/bvs/publicacoes/manual_acolhimento_classificacao_risco_obstetricia.pdf

Ministério da Saúde (2018). Boletim Epidemiológico no 54/2018: Semana Epidemiológica (SE) 45/2018: Monitoramento integrado de alterações no crescimento e desenvolvimento relacionadas à infecção pelo vírus Zika e outras etiologias infecciosas, até a Semana Epidemiológica 45 de 2018. https://portalarquivos2.saude.gov.br/ images/pdf/2018/dezembro/14/2018-061.pdf 
Psicologia: Ciência e Profissão 2021 v. 41 (n.spe 3), e193951, 1-17.

Nascimento, A. M. C. (2018). Sobrecarga em cuidadores de crianças microcefálicas com síndrome da zika congênita [dissertação de mestrado, Universidade Federal de Pernambuco]. Attena Repositório Digital da UFPE. https://repositorio.ufpe.br/handle/123456789/31836

Oliveira, D. C. (2008). Análise de conteúdo temático-categorial: uma proposta de sistematização. Revista de Enfermagem da UERJ, 16(4), 56976.

Oliveira, M. C., \& Sá, S. M. (2017) A experiência parental após o diagnóstico da microcefalia por zika virus: um estudo de caso. Revista Pesquisa em Fisioterapia, 7(4), 511517. https://doi.org/10.17267/2238-2704rpf.v7i4.1602

Oliveira, M. O., Moreira, R. C. R., Lima, M. M., \& Melo, R. O. (2018). Vivências de mães que tiveram filhos com microcefalia. Revista Baiana de Enfermagem, 32, e26350. https:// doi.org/10.18471/rbe.v32.26350

Osório, L. C., \& Valle, M. E. P. (2009). Manual de terapia familiar. Artmed.

Pereira, R. (2008). Anatomia da diferença: normalidade, deficiência e outras invenções. Casa do Psicólogo.

Prado, A. F. A. (2013). Família e deficiência. In C. M. O. Cerveny (Org.), Família e....: comunicação, divórcio, mudança, resiliência, deficiência, lei, bioética, doença, religião e drogadição (pp. 8598). Casa do Psicólogo.

Roecker, S., Mai, L. D., Baggio, S. C., Mazzola, J. C., \& Marcon, S. S. (2012). A vivência de mães de bebês com malformação. Escola Anna Nery, 16(1), 1726. https://doi.org/10.1590/S1414-81452012000100003.

Sá, F. E., Andrade, M. M. G., Nogueira, E. M. C., Lopes, J. S. M., Silva, A. P. E. P., \& Assis, A. M. E. V. (2017) Produção de sentidos parentais no cuidado de crianças com microcefalia por vírus zika. Revista Brasileira em Promoção da Saúde, 30(4), 110. https://doi.org/10.5020/18061230.2017.6629

Santos, L. P. D., Gonçalves, T. B. S., Cordeiro, A. L. L., \& Santos, A. S. (2018). Avaliação da qualidade de vida das mães de crianças com microcefalia. Revista Brasileira de Saúde Funcional, 5(2), 1117.

Santos, M. A., \& Pereira-Martins, M. L. P. L. (2016). Estratégias de enfrentamento adotadas por pais de crianças com deficiência intelectual. Ciência \& Saúde Coletiva, 21(10), 32333244. https://doi.org/10.1590/ 1413-812320152110.14462016

Sawaia, B. (2010). O sofrimento ético-político como categoria de análise da dialética exclusão/inclusão. In B. Sawaia (Org.), As artimanhas da exclusão: análise psicossocial e ética da desigualdade social (10a ed., pp. 99120). Vozes.

Scott, R. P., Quadros, M. T., Rodrigues, A. C., Lira, L. C., Matos, S. S., Meira, F., \& Saraiva, J. (2017). A epidemia de zika e as articulações das mães num campo tensionado entre feminismo, deficiência e cuidados. Cadernos de Gênero e Diversidade, 3(2), 7392. http://doi.org/10.9771/cgd.v3i2.22013

Silva, A. C. R., Matos, S. S., \& Quadros, M. T. (2017). Economia política do zika: Realçando relações entre Estado e cidadão. Anthropológicas, 28(1), 223246. https://doi.org/10.51359/2525-5223.2017.231440

Silva, B. L. C., Furtado M. P. T., Pereira, W. S., \& Malkes, N. F. A. (2018). Síndrome congênita do zika vírus: Repercussões na saúde materna [Trabalho de conclusão de curso, Faculdade ASCES]. Repositório Digital ASCES. http://repositorio.asces.edu.br/handle/123456789/1730

Silva, D. R. (2009). Famílias e situações de luto. In L. C. Osório, \& M. E. P.Valle, Manual de terapia familiar (pp. 373398). Artmed.

Silva, E. H. P., Girão, E. R. C., \& Cunha, A. C. B. (2016). Enfrentamento do pai frente à malformação congênita do filho antes e depois do nascimento. Estudos e Pesquisas em Psicologia, 16(1), 180199. https://doi.org/10.12957/ epp.2016.24838

Silvestre, H. S. (2018). Direito fundamental ao transporte para garantia de acesso à saúde das mulheres e crianças vítimas da epidemia do vírus Zika [trabalho de conclusão de curso, Universidade de Brasília]. Biblioteca Digital da Produção Intelectual Discente da Universidade de Brasília. http://bdm.unb.br/bitstream/10483/21671/1/ 2018_HellenSouzaSilvestre_tcc.pdf

Vale, P. R. L. F. (2018) Experiências de famílias de crianças com microcefalia por Zika vírus [dissertação de mestrado, Universidade Estadual de Feira de Santana]. Biblioteca Digital deTeses e Dissertações UEFS. http://tede2.uefs.br:8080/ bitstream/tede/680/2/DISSERTA\%c3\%87\%c3\%83O\%20PAULO\%20ROBERTO\%20finalz\%c3\%a3o\%2009\%2003.pdf

Valle, J. W., \& Connor, D. J. (2014). Ressignificando a deficiência: da abordagem social às práticas inclusivas na escola. AMGH.

Vasconcelos Filho, J. M., \& Coutinho, S. (2017). O ativismo digital brasileiro. Fundação Perseu Abramo. 
Yin, R. K. (2015). Estudo de caso: planejamento e métodos (5a ed.). Artmed.

Zago, L. F., \& Pimentel, P. R. (2017). Esquecimentos midiáticos: mãe-sozinha, pai-ausente, bebê-monstro e a epidemia de Zika na Folha de S.Paulo on-line. Passagens, 8(2), 152172.

Zornig, S.A. (2012). Construção da parentalidade: da infância dos pais ao nascimento do filho. In C. A. Piccinini, \& P. Alvarenga (Orgs.), Maternidade e paternidade: a parentalidade em diferentes contextos (pp. 1734). Casa do Psicólogo.

Jany Helem de Almeida Santos

Psicóloga graduada pelo Centro Universitário Maurício de Nassau (Uninassau), Campina Grande - PB. Brasil.

E-mail: janyhelem_cg@hotmail.com

(1) https://orcid.org/0000-0003-0420-0803

Aponira Maria de Farias

Doutoranda em Saúde Coletiva pela FioCruz Minas (Instituto René Rachou), Belo Horizonte - MG. Brasil.

E-mail: aponira@yahoo.com

(1) https://orcid.org/0000-0003-3491-1198

Endereço para envio de correspondência:

Aponira Maria de Farias. Caixa Postal 343. Centro. CEP: 58400-970. Campina Grande - PB. Brasil.

Recebido 07/04/2018

Aceito 23/10/2019

Received 04/07/2018

Approved 10/23/2019

Recibido 07/04/2018

Aceptado 23/10/2019

Como citar: Santos, J. H. A., \& Farias, A. M. (2021). Ser mãe de criança com microcefalia: Do ideal ao real na síndrome congênita do zika vírus (SCZV). Psicologia: Ciência e Profissão, 41 (n.spe 3), 1-17. https://doi.org/ $10.1590 / 1982-3703003193951$

How to cite: Santos, J. H. A., \& Farias, A. M. (2021). Being a mother of a child with microcephaly: From ideal to real in the zika virus congenital syndrome (ZVCS). Psicologia: Ciência e Profissão, 41 (n.spe 3), 1-17. https://doi.org/ $10.1590 / 1982-3703003193951$

Cómo citar: Santos, J. H. A., \& Farias, A. M. (2021). Ser madre de un niño con microcefalia: De lo ideal a lo real en síndrome congénito asociado a virus del zika (SCZV). Psicologia: Ciência e Profissão, 41 (n.spe 3), 1-17. https:// doi.org/10.1590/1982-3703003193951 